\title{
Silver-containing Cation Exchange Resin: Synthesis and Application
}

\author{
Renat KHAYDAROV ${ }^{1 *}$, Murodjon ABDUKHAKIMOV ${ }^{1}$, Ilnur GARIPOV ${ }^{1}$, \\ Ilkham SADIKOV ${ }^{1}$, Praveen Thaggikuppe KRISHNAMURTHY ${ }^{2}$, \\ Svetlana EVGRAFOVA ${ }^{3,4}$
}

\author{
${ }^{1}$ Institute of Nuclear Physics, Academy of Sciences of Uzbekistan, 100214, 1 Xuroson, Tashkent, Uzbekistan \\ ${ }^{2}$ JSS College of Pharmacy, Ootacamund, Off Campus JSS, India \\ ${ }^{3}$ Sukachev Institute of Forest of the Siberian Division of the Russian Academy of Sciences, 660036, Krasnoyarsk, Russia \\ ${ }^{4}$ Institute of Fundamental Biology and Biotechnology, Siberian Federal University, 79 Svobodny Avenue, 660041 \\ Krasnoyarsk, Russian Federation
}

crossref http://dx.doi.org/10.5755/j02.ms.28473

Received 07 February 2021; accepted 07 April 2021

\begin{abstract}
Cation exchange resins are widely used for water softening and demineralization all over the world. Deposition, metabolism, and growth of bacteria and fungi on the resin beads cause capacity and performance losses, especially during repeated use in cyclic and long-term operations. Over the last decades, modification of different materials by silver nanoparticles (AgNPs) has demonstrated to present significant opportunities in mitigating biofouling problems. The paper deals with a novel facile technique of introducing silver colloids (AgC) into cation exchange resin, providing the formation of silver micro- and nano-inclusions on the cation resin beads. The scanning electron microscope (SEM) measurements have confirmed a spherical shape and uniform distribution of AgC (50-1000 nm) on the surface of the resin. To evaluate the antibacterial and fungicidal properties of AgC on the cation resin beads, we have used Aureobasidium sp., Penicillium sp., and Staphylococcus aureus cultures. AgC coating has proved to efficiently prevent bacteria/biofilm growth on the cation resin beads and thereby significantly increase the service life of the cation exchange resin, especially in hot climatic conditions. Possible antibiofouling mechanisms of the modified nanocomposite cationite have been discussed. Since 2020, the modified silver-containing cationite has been successfully utilized for water softening systems of boiler equipment in Uzbekistan, demonstrating the suitability of the suggested facile coating technique for reducing fouling of cation-exchange resin.

Keywords: cationite, water hardness, silver nanoparticle, ion-exchange, water softening.
\end{abstract}

\section{INTRODUCTION}

Water softening is the process of removing the dissolved calcium and magnesium salts that cause hardness in water. Cation exchange resins are known to be widely used in water purification equipment to soften water due to the long life of the resins and their cheap maintenance costs [1]. Our data of operating softening systems in hot climatic conditions of Uzbekistan has clearly demonstrated that a rapid contamination of the cation exchanger with microorganisms often occurs [2]. It leads to the destruction of the cation exchanger granules and a significant decrease of its exchange capacity, which leads to a sharp reduction in the service life and operation of expensive water softening systems. To solve this problem, we have suggested the preparation and subsequent application of a strong acid cationite with silver nano-inclusions into water softening system. AgC are known to stop bacterial growth due to their superior antibacterial properties [2, 3].

It is expected that the application of $\mathrm{AgC}$ in the structure of the cation exchanger will thereby significantly increase its service life while maintaining a high value of its exchange capacity. Over the recent decades, a large number of scientific publications have been devoted to the synthesis of both sorption and composite ion-exchange

\footnotetext{
* Corresponding author. Tel.: +998-91-1641508.

E-mail address: renat@inp.uz (R. Khaydarov)
}

materials with micro- and nanosized inclusions of metal nanoparticles [1, 4-8]. However, despite the recent successes, the problem of obtaining and practical application of metal-containing ion-exchange materials with bactericidal properties remains one of the most intriguing in the water treatment science.

\section{MATERIALS AND METHODS}

Silver nitrate $\mathrm{AgNO}_{3}$, hydrazine, natural polysaccharides including sodium alginate and quercetin (Sigma Aldrich, UK), and commercially available KU-2-8 cationite (TOKEM, Russia) were used in the as-received condition. KU-2-8 is a strong acid cation exchange resin (gel type) with high capacity, which is analogous to Purolite C100E resin. Its polymer structure is composed of styrene-divinylbenzene containing sulfonic acid functional groups. Ion-exchange saturation of the KU-2-8 cationite with silver ions was carried out with full and partial saturation for silver. A series of experiments was carried out by using weighed portions of cation exchanger in the Na-form of the same weight (1 $\mathrm{g}$ each), the silver concentration varied in the range $0.01-0.4 \mathrm{~mol} / \mathrm{l}$, the volume of the aqueous phase was $5 \mathrm{ml}$ for each weighed portion. The sorption of silver was carried out in a static mode for 1 hour, after which the samples were washed with distilled water and the recovery of silver was carried out in the cation resin matrix. 
The saturation of the cation exchanger with silver ions was also carried out in a dynamic mode by using a glass column (25 mm in diameter), into which $10 \mathrm{~g}$ of the cation exchanger was placed, and the working layer height was $35 \mathrm{~mm}$. A solution of silver nitrate with a concentration of $0.01 \mathrm{~mol} / \mathrm{l}$ was passed through the cation resin layer at a rate of $5 \mathrm{ml} / \mathrm{min}$ until the resin was completely saturated. The total exchange capacity of the cation exchanger for silver obtained as a result of the experiment was amounted to $200 \mathrm{mg} / \mathrm{g}$, which corresponds to approximately $1.9 \mathrm{mmol} / \mathrm{g}$. The concentration of silver ions in our experiments was determined by the potentiometric method using an ion-selective electrode "ELIS-131Ag" type. The range of determined concentrations of silver ions: from $5 \times 10^{-7}$ to $10^{-1} \mathrm{~mol} / \mathrm{l}$. For recovery procedures, we used freshly prepared solutions of sodium borohydride with a concentration of $0.05-0.1-0.2-1 \%$, and the concentration of sodium alginate was of $0.1-1.0 \%$.

Surfaces of the granules of the cation resin modified with colloidal silver particles have been examined by scanning electron microscopy (Zeiss SEM EVO MA10).

Samples for microbiological studies were prepared as follows: a single layer of tightly packed porous granules of a cation exchanger (both initial and modified with AgC) was clamped between two rectangular paper substrates using small amounts of silicone. The resulting substrates were immersed in agar after pouring it into Petri dishes. Meat-peptone agar was used for bacteria, and Wort Agar was used for mushrooms. The bacterial suspension or spore suspension of the studied fungi was spread with a spatula over the agar surface. Visual registration of the results was carried out on the 3rd day for bacteria and on the 7th day for fungi. The antibacterial effect of AgC diffused into the agar was determined by the clearing zone at the bacterial lawn or the absence of fungal growth in the zone of the substrate with the cation exchanger.

\section{RESULTS AND DISCUSSION}

The formation of silver particles in the ion exchanger matrix (see Fig. 1) is a two-stage process. At the first stage, silver ions are sorbed from the solution and localized near fixed groups of the ion exchanger:

$\mathrm{RSO}_{3} \mathrm{Na}+\mathrm{AgNO}_{3} \rightarrow \mathrm{RSO}_{3} \mathrm{Ag}+\mathrm{NaNO}_{3}$.

In the second stage, silver ions were reduced to nanoparticles with a freshly prepared sodium borohydride solution:

$2 \mathrm{RSO}_{3} \mathrm{Ag}+2 \mathrm{NaBH}_{4}+6 \mathrm{H}_{2} \mathrm{O} \rightarrow 2 \mathrm{Ag} \downarrow+7 \mathrm{H}_{2} \uparrow+2 \mathrm{H}_{3} \mathrm{BO}_{3}$ $+2 \mathrm{RSO}_{3} \mathrm{Na}$.

Recovery of $\mathrm{Ag}^{+}$cations in the matrix of granular cationite KU-2-8 is accompanied by a partial transition of nanosized silver particles from the ionite phase to the solution, which is characterized by staining of the reducing agent solution. The surface of cationite samples with a high silver content is covered with a layer of metallic silver during the reduction process. Total exchange capacity of cationite KU-2-8 for silver ions was of $2.05 \mathrm{mmol} / \mathrm{g}$. Some characteristics of KU-2-8 cation exchanger modified by AgC are shown in Table 1.
The introduction of nanoscale silver inclusions using borohydride reduction makes it possible to obtain nanocomposites with different distributions of reduced silver in the ion exchanger phase.

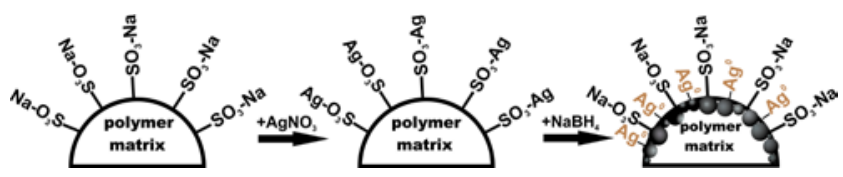

Fig. 1. Synthesis of silver nanosized colloids on the surface of polymer ion-exchange matrix

Table 1. Physical and chemical characteristics of KU-2-8 resin modified by AgC

\begin{tabular}{|l|c|}
\hline \multicolumn{1}{|c|}{ Characteristics } & Value \\
\hline Matrix & Styrene-divinylbenzene \\
\hline Functional group & Sulfonic acid \\
\hline Polymer structure & Gel \\
\hline Appearance & Spherical beads \\
\hline Particle size range, mm & $0.5-1.25$ \\
\hline Moisture retention, \% & $48-58$ \\
\hline Uniformity coefficient, max & 1.7 \\
\hline Osmotic stability, \%, min & 94.5 \\
\hline
\end{tabular}

As a result of the conducted studies, it was found that the concentration of reducing agent has a significant effect on the distribution of reduced silver. In the chemical reduction of $\mathrm{Ag}^{+}$cations in the $\mathrm{KU}-2-8$ matrix, a decrease in the concentration of sodium borohydride promotes the reduction of silver cations mainly in the surface layer of the grain, leading to the formation of a conductive layer of metallic silver. Increase of the concentration of reducing agent contributes to the production of volume-modified samples.

Based on the obtained results, the optimal conditions for obtaining KU-2-8 cationite modified with silver ions are as follows:

1. Concentration of silver nitrate solution is $0.5 \mathrm{~mol} / \mathrm{l}$;

2. Volume of silver nitrate solution taken for cationite treatment is $10-50 \mathrm{ml}$;

3. Contact time of silver nitrate solution with cationite in static mode is 1 hour;

4. Washing the cation exchange resin with distilled water;

5. Reduction of silver ions present in the cationite matrix with a freshly prepared sodium borohydride solution with a concentration of $0.05-0.1 \%$;

6. Washing cationite with distilled water from recovery products.

The nanocomposite cationite with different concentrations of AgC in its structure is shown in Fig 2.

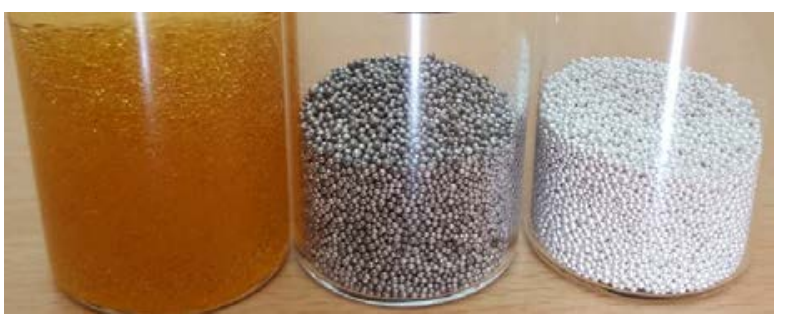

Fig. 2. Photo of the initial new cationite KU-2-8 (left) and nanocomposite cationite synthesized with $\mathrm{AgC}$ concentration of $0.1 \mathrm{mmol} / \mathrm{g}$ (middle) and $0.25 \mathrm{mmol} / \mathrm{g}$ (right) 
Fig. 3 shows the nanocomposite cationite surface obtained using a scanning electron microscope (SEM). As one can see from the figure, the silver particles on the surface of cationite have a spherical shape, and their size varies in the range from tens of $\mathrm{nm}$ to $1000 \mathrm{~nm}$.

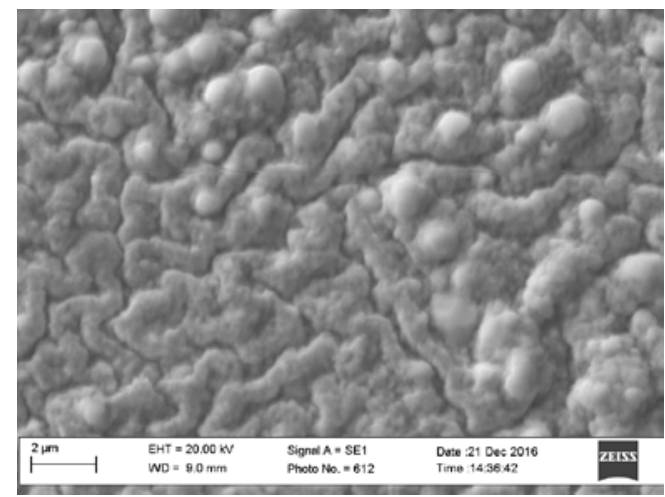

Fig. 3. Typical SEM picture of the nanocomposite cationite surface

Over the last decade, authors of the article have accumulated considerable experience in the field of modifying various materials with nanosilver to impart biocidal properties to them [9-15]. By analogy with the experiments described in our previous publications [2, 9-11], we performed a comparative qualitative analysis of the antimicrobial effect of nanocomposite cationite in relation to microscopic fungal cultures Aureobasidium sp. and Penicillium sp., and bacteria Staphylococcus aureus using agar diffusion method.

As one can see from Fig. 4, the microbiological tests performed demonstrate a pronounced antimicrobial effect manifested by AgC-modified cationite granules. It's necessary to note that the fungi spores Aureobasidium sp. Fig. $4 \mathrm{a}$ and Penicillium sp. Fig. $4 \mathrm{~b}$ suspended in water cannot distribute evenly on the agar surface. Nevertheless, around sample 2 we can clearly see less number of fungi that shows inhibition effect provided by AgC. Introduction of cooloidal silver particles into the cationite structure allows preventing the growth of bacteria, microscopic fungi, and biofilms on its surface, and thereby potentially increase its service life.

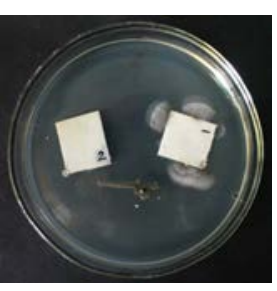

a

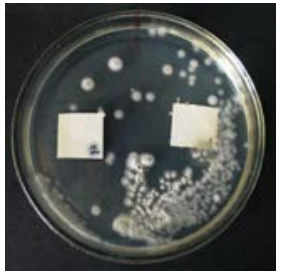

b

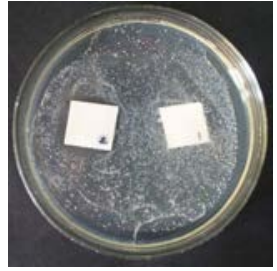

C
Fig. 4. Growth of: a-Aureobasidium sp.; b-Penicillium sp.; $\mathrm{c}-\mathrm{S}$. aureus on samples with cationite (initial \#1 and modified by silver colloid \#2 with the concentration of $0.1 \mathrm{mmol} / \mathrm{g}$ )

The mechanism of antimicrobial action of nano-sized AgC is not sufficiently understood yet. Different postulations were suggested in the literature to elucidate the changes occur into bacterial cell components after AgC treatment. Most scientists assume the bactericidal effect originates from Ag ions released from AgC [16]. Namely, when exposed to dissolved oxygen in water medium, AgCs release small amounts of Ag according to equation:

$\mathrm{O}_{2(\mathrm{aq})}+4 \mathrm{H}_{3} \mathrm{O}^{+}+4 \mathrm{Ag}_{(\mathrm{s})} \rightarrow 4 \mathrm{Ag}^{+}{ }_{(\mathrm{aq})}+6 \mathrm{H}_{2} \mathrm{O}$.

Another approach is based on the work of [17] who found silver nanoparticles attached to the cell membrane and inside the bacteria by TEM analysis. As Ag possesses high affinity for sulfur and phosphorous compounds, it can be anticipated that silver nanoparticles will react with sulfur-rich protein in the bacteria cell membrane and interior of the cell or with phosphorous-containing compounds such as DNA. Therefore, the detected morphological changes in the cell membrane of bacteria and possible damage of DNA initiated by reaction with silver nanoparticles have an adverse effect on the respiratory chain or cell division processes, causing cell death.

The developed nanocomposite cationite has a potential of widespread commercialization with further introducing in water softening systems, especially those used for boiler equipment, as well as in equipment (injection molding machines, extruders, steam generators, cooling towers, reverse osmosis systems, etc.) that requires the supply of initial soft water. Our studies have shown that it is sufficient to introduce up to $10 \%$ of the developed nanocomposite cationite out of the total volume of highly acidic cation exchange resin (for example, Purolite C100, KU-2-8, Seplite SC 130, etc.) inside chemical water softening columns to ensure the desired effect.

The effect of reducing oxygen dissolved in water by nanocomposite cationite was also revealed. Considering this process, we can distinguish the following stages that occur in the nanocomposite grain: internal diffusion of oxygen through the pores of the nanocomposite, adsorption oxygen on nanosilver centers, redox reaction of oxygen with AgC. The redox reaction ends with the formation of silver ions or with the formation of oxides and hydroxides. Thus, the developed nanocomposite cationite can perform the function of removing dissolved oxygen from water, but this assumption requires additional research.

Since 2020, the nanocomposite cationite has been succesefully commercialized in Uzbekistan within the framework of the modernization of Republican heating system. The modified water softening systems provide the required softening in accordance with the standards for water hardness of the boiler equipment used, while traditional chemical water treatment systems in hot climatic conditions of Uzbekistan after the same period, in some cases, start requiring the replacement of cationite caused by the growth of bacterial formations and algae in the layers of ion-exchange resin, reducing its exchange capacity. In-field studies have clearly demonstrated the suitability of the proposed simple coating method for reducing the fouling of KU-2-8 resin when it is exposed to complex, multicomponent effluents found under natural environment conditions.

\section{CONCLUSIONS}

The technique of introducing silver micro- and nanoinclusions into the strongly acid cation resin KU-2-8 has been developed. The method ensures the formation of a 
layer of silver colloids on the surface of cation resin granules. Silver particles on the surface of the cation exchanger have a spherical shape and their size varies in the range from 50 to $1000 \mathrm{~nm}$. Using AgC in the structure of the cation exchanger prevents the growth of bacteria and biofilms on its surface and thereby significantly increases its service life. The cation exchanger modified by AgC can be widely used as part of water softening systems designed to increase efficiency, eliminate scale, and deposits on heat transfer surfaces in boiler equipment.

\section{REFERENCES}

1. Sheldeshovz, N.V., $\quad$ Melnikov, S.S., $\quad$ Soloveva, T.T., Bespalov, A.V., Levchenko, V.F., Buikliskii, V.D., Zabolotskii, V.I. The Effect of Silver Ions and Nanoparticles of the Properties of Ion-exchange Materials Russian Journal of Electrochemistry 47 (2) 2011: pp. $200-208$. https://doi.org/10.1134/S1023193511020157

2. Garipov, I., Khaydarov, R.R., Khaydarov, R.A., Gapurova, O. Silver Nanoparticles as a Biocide for Water Treatment Applications Advanced Research in Nanosciences for Water Technology 2019: pp. 407-419. https://doi.org/10.1007/978-3-030-02381-2_18

3. Bachhav, P.A., Shroff, R.M., Shirkhedkar, A.A. Silver Nanoparticles: A Comprehensive Review on Mechanism, Synthesis and Biomedical Applications Asian Journal of Pharmaceutical Research 10 (3) 2020: pp. 202-212. https://doi.org/10.5958/2231-5691.2020.00035.0

4. Biswas, K., Ghosh, S., Basu, B. Ion-exchange Resins and Polypeptide Supported Catalysts: A Critical Review Current Green Chemistry 7 (1) 2020: pp. 40-52. https://doi.org/10.2174/2213346107666200204125435

5. Torres-Flores, E.I., $\quad$ Flores-López, N.S., MartínezNúñez, C.E., Tánori-Córdova, J.C., Flores-Acosta, M., Cortez-Valadez, M. Silver Nanoparticles in Natural Zeolites Incorporated into Commercial Coating: Antibacterial Study Applied Physics A 127 2021: pp. 71. https://doi.org/10.1007/s00339-020-04227-5

6. Burgers, R., Eidt, A., Frankenberger, R., Rosentritt, M., Schweikl, H., Handel, G., Hahnel, S. The Anti-adherence Activity and Bactericidal Effect of Microparticulate Silver Additives in Composite Resin Materials Archives of Oral Biology 54 2009: pp. 595-601.

https://doi.org/10.1016/j.archoralbio.2009.03.004

7. Jiraroj, D., Tungasmita, S., Tungasmita, D.N. Silver Ions and Silver Nanoparticles in Zeolite A: Composites for Antibacterial Activity Powder Technology 264 2014: pp. 418-422. https://doi.org/10.1016/j.powtec.2014.05.049
8. Siddiqi, K.S., Husen, A., Rao, R.A. A Review on Biosynthesis of Silver Nanoparticles and Their Biocidal Properties Journal of Nanobiotechnology 16 (1) 2018: p. 14. https://doi.org/10.1186/s12951-018-0334-5

9. Khaydarov, R.A., Khaydarov, R.R., $\quad$ Evgrafova, S., Estrin, Y. Using Silver Nanoparticles as an Antimicrobial Agent. Biodefence: Chemistry and Biology, Springer, Netherlands 2011: pp. 169-177. http://dx.doi.org/10.1007/978-94-007-0217-2_18

10. Garipov, I.T., Khaydarov, R.R., Gapurova, O.U., Khaydarov, R.A., Firdaus, M.L., $\quad$ Efimova, I.L., Evgrafova, S.Y. Silver Nanoparticles as a New Generation of Antimicrobial Prophylaxis Journal of Siberian Federal University. Biology 12 (3) 2019: pp. 266-276. http://dx.doi.org/10.17516/1997-1389-0301

11. Khaydarov, R.R, Khaydarov, R.A., Gapurova, O., Evgrafova, S., Wagner, S., Cho, S.Y. Environmental and Human Health Issues of Silver Nanoparticles Applications. Environmental Security and Ecoterrorism NATO Science for Peace and Security Series C: Environmental Security 2011: pp. $117-127$. http://dx.doi.org/10.1007/978-94-007-1235-5_9

12. Sambale, F., Wagner, S., Stahl, F., Khaydarov, R.R., Scheper, T., Bahnemann, D. Investigations of the Toxic Effect of Nanoparticles on Mammalian Cell Lines Journal of Nanomaterials Article ID 136765 2015: pp. 9. https://doi.org/10.1155/2015/136765

13. Khaydarov, R.A, Khaydarov, R.R., Gapurova, O., Estrin, Y. A Novel Method of Continuous Fabrication of Aqueous Dispersions of Silver Nanoparticles International Journal of Nanoparticles 3 2010: pp. 77-91. https://doi.org/10.1504/IJNP.2010.033223

14. Khaydarov, R.A, Khaydarov, R.R., Cho, S. Natural Disaster: Prevention of Drinking Water Scarcity. Threats to Global Water Security. Springer, Netherlands. 2009: pp. $381-384$. https://doi.org/10.1007/978-90-481-2344-5_45

15. Yaqoob, A.A., Parveen, T., Umar, K., Ibrahim, M., Nasir, M. Role of Nanomaterials in the Treatment of Wastewater: A Review Water 12 (2) 2020: pp. 495. http://dx.doi.org/10.3390/w12020495

16. Radetić, M. Functionalization of Textile Materials with Silver Nanoparticles Journal of Materials Science 48 2013: pp. 95-107. http://dx.doi.org/10.1007/s10853-012-6677-7

17. Morones, J.R., Elechiguerra, J.L., Camacho, A., Holt, K., Kouri, J.B., Ramírez, J.T., Yacaman, M.J. The Bactericidal Effect of Silver Nanoparticles Nanotechnology 16 2005: pp. $2346-2353$. http://dx.doi.org/10.1088/0957-4484/16/10/059

(c) Khaydarov et al. 2022 Open Access This article is distributed under the terms of the Creative Commons Attribution 4.0 International License (http://creativecommons.org/licenses/by/4.0/), which permits unrestricted use, distribution, and reproduction in any medium, provided you give appropriate credit to the original author(s) and the source, provide a link to the Creative Commons license, and indicate if changes were made. 